\title{
11077I- INTEERThesis

\section{CAPACITANDO A ADAPTAÇÃO À MUDANÇA CLIMÁTICA EM ÁREAS URBANAS: UMA ABORDAGEM DE GOVERNANÇA LOCAL}

\section{ENABLING CLIMATE CHANGE ADAPTATION IN URBAN AREAS: A LOCAL GOVERNANCE APPROACH}

\section{CAPACITANDO LA ADAPTACIÓN AL CAMBIO CLIMÁTICO EN ÁREAS URBANAS: UN ENFOQUE DE GOBERNABILIDAD LOCAL}

\section{Rafael D'Almeida Martins ${ }^{1}$ \\ Leila da Costa Ferreira ${ }^{2}$}

\section{RESUMO:}

A mudança climática tornou-se o centro do debate público nos últimos anos. Cidades e áreas urbanas são vulneráveis aos impactos da mudança climática. Metade da população mundial vive em áreas urbanas e em 2050 essa proporção deverá aumentar ainda mais segundo estatísticas recentes. Além disso, mais de 80 por cento das cidades estão localizadas no litoral e próximas a rios, tornando-as predispostas ao aumento de tempestades, inundações e elevação do nível do mar. Os governos locais desempenham um papel importante na implementação de políticas de mudança climática. A evidência empírica mostra que esses governos aparecem muitas vezes como atores importantes coordenando, facilitando e implementando ações relativas à mudança do clima sozinhos ou em parceria com diferentes atores. Este artigo revisa a literatura sobre cidades e mudança climática e explora os elementos que permitem que os governos locais empreendam ações na direção da adaptação em relação à mudança climática. Também se discute os riscos e a vulnerabilidade das áreas urbanas com foco na implementação de estratégias de adaptação. Fatores como a boa governança, instituições democráticas e participativas e a disponibilidade de diferentes tipos de recursos, conhecimentos e informações sobre a que e como se adaptar, além da presença de um empreendedor político aparecem muitas vezes apoiando essas ações.

Palavras-chave: Cidades. Governos locais. Mudança climática. Adaptação. Política climática urbana. Governança local.

\footnotetext{
${ }^{1}$ Doutorando do Programa em Ambiente e Sociedade, Instituto de Filosofia e Ciências Humanas (IFCH) e Núcleo de Estudos e Pesquisas Ambientais (NEPAM) da Universidade Estadual de Campinas (UNICAMP). E-mail: rdamartins@gmail.com

${ }^{2}$ Professora Titular da Universidade Estadual de Campinas (UNICAMP) do Instituto de Filosofia e Ciências Humanas (IFCH), Núcleo de Estudos e Pesquisas Ambientais (NEPAM), Doutora em Sociologia pela Universidade Estadual de Campinas (UNICAMP) E-mail: leilacf@unicamp.br
} 


\section{ABSTRACT:}

Climate change became the center of public concern in the last years. Cities and urban areas are particularly vulnerable to the effects of climate change. Half of the global population currently lives in urban areas and by 2050 this proportion is estimated to increase. In addition, more then 80 percent of the cities are located on the shore and near rivers, making them predisposed to increased storms, floods and sea-level rise. Local governments play an important role in implementing climate change policies. The empirical evidence shows that local governments often appear as key actors in coordinating, facilitating and implementing climate change actions alone or cooperating with an array of different actors. This paper reviews the literature on cities and climate change and explores the elements that enable local governments to take action in terms of climate adaptation. It also discusses the risks and vulnerability of cities looking at the implementation of climate change adaptation strategies. Enabling elements such as good governance, democratic and participatory institutions, availability of different types of resources, knowledge and information on what and how to adapt, as well as the presence of a local political entrepreneur often appear supporting climate change adaptation.

Keywords: Cities. Local governments. Climate change. Adaptation. Urban climate policy. Local governance.

\section{RESUMEN:}

El cambio climático se ha convertido en el centro del debate público en los últimos años. Ciudades y zonas urbanas son vulnerables a los impactos del cambio climático. La mitad de la población mundial vive en zonas urbanas y en 2050 esta proporción aumentará aún más según estadísticas recientes. Además, más del 80 por ciento de las ciudades están situadas en la costa y cerca de ríos, haciéndolas predispuestas a una mayor posibilidad de tormentas, inundaciones y elevación del nivel del mar. Los gobiernos locales desempeñan un papel importante en la implementación de políticas de cambio climático. La evidencia empírica muestra que esos gobiernos a menudo aparecen como actores clave en la coordinación, facilitación y ejecución de acciones relacionadas con el cambio climático en solitario o en colaboración con diferentes actores. Este artículo revisa la literatura sobre las ciudades y el cambio climático y explora los elementos que permiten que los gobiernos locales tomen medidas hacia la adaptación al cambio climático. También se analizan los riesgos y la vulnerabilidad de las zonas urbanas centradas en la implementación de estrategias de adaptación. Factores tales como la buena gobernabilidad, instituciones democráticas y participativas y la disponibilidad de diferentes tipos de recursos, conocimientos e información sobre qué y cómo adaptarse, además de la presencia de un emprendedor político parecen muchas veces apoyando esas acciones.

Palabras clave: Ciudades. Gobiernos locales. Cambio climático. Adaptación. Política climática urbana. Gobernabilidad local. 


\section{INTRODUCTION}

Climate change has recently become the center of public debate and it is now everywhere in the media on a daily basis (GIDDENS, 2009). Although the major part of the scientific community has been expressing serious concerns about global warming and different types of global environmental change for at least 30 year, society has only awaked for the problem with the publication of the Fourth Assessment Report (AR4) by the Intergovernmental Panel on Climate Change (IPCC) in 2007. IPCC, a highly influential and leading scientific body for the assessment of climate change, established by the United Nations Environment Program (UNEP) and the World Meteorological Organization (WMO), stated on its latest assessment report that climate change is unequivocal and its impacts are underway (SOLOMON et al., 2007). These impacts are likely to play out everywhere: in cities as well as in rural areas, seacoasts, inland lakes and rivers, forests and other settlements (PARRY et al., 2007; BICKNELL, DODMAN \& SATTHERTHWAITE, 2009).

Although surrounded by a great degree of uncertainty in terms of the real consequences of global warming and climate change for specific regions and places, the scientific community predicts a wide range of climate change impacts including flooding of low elevation coastal zones by sea level rise (MCGRANAHAN, BALK \& ANDERSON, 2009; 2007), increased intensity of extreme weather events, and heat waves and stress and damage to vulnerable ecosystems and habitats (PARRY et al., 2007). These will have major impacts on human health (CONFALONIERI et al., 2007; COFALONIERI, 2008; CONFALONIERI et al., 2002; CONFALONIERI, MARINHO \& RODRIGUEZ, 2009), and on infrastructure and environment (WILBANKS et al., 2007). In cities, these impacts will negatively impact water (MARENGO, 2008), sewage, energy distribution, buildings and transportation systems, increasing illness and deaths, especially among the most vulnerable population (SATTERTHWAITE et al., 2009; BICKNELL, DODMAN \& SATTERTHWAITE, 2009; SATTERTHWAITE, 2008; MOSER \& SATTERTHWAITE, 2008; SATTERTHWAITE et al., 2007; HUNT \& WATKISS, 2007).

The relationship between cities and climate change is based on a complex R. Inter. Interdisc. INTERthesis, Florianópolis, v.7, n.2, p. 241-275, jul/dez. 2010 
balance between vulnerability and responsibility (ROBINSON \& GORE, 2005). Cities are vulnerable to a wide range of climate change impacts. At the same time, the local authority, such as municipality, county and province, and their legal responsibility provide opportunities to influence many activities that contribute to climate change and respond in terms of both mitigation and adaptation policies (SATTERTHWAITE, 2008; ROBINSON \& GORE, 2005; BULKELEY \& BETSILL, 2003).

By using mitigation cities can substantially reduce their environmental impact and consequently transform their infrastructure, especially transport, use of energy in their buildings, and the behavior and consumption patterns of their residents improving the global environment. By using adaptation cities can become resilient to the impacts of climate change (DAWSON, 2007). Although urban transformations, like those caused by climate change, will take tens of years and are probably reliant on significant developments in how cities are governed and planned, cities have a very direct interest in both mitigating environmental change and adapting to climate change (SATTERTHWAITE et al., 2009; SATTERTHWAITE et al., 2007).

If no action is taken across the world over the next years, research suggests that many aspects of their environment will deteriorate and the life and even viability of cities will be threatened (HUNT, 2004; SATTERTHWAITE et al., 2009). Many cities are on coastal plains, which will be subject to more frequent flooding from increased rainfall and sea level rise. In developing countries, one of the most critical environmental issues is the shortage of clean drinking water and sanitation in urban areas with huge and growing populations (HUNT, 2004; SATTERTHWAITE et al., 2007; SATTERTHWAITE, 2008; MULLER, 2009).

It is clear that society cannot wait for scientific certainties to adopt measures that mitigate the global warming and adapt cities to protect its people and infrastructure from climate and environmental change (RIBEIRO, 2008a). It is, therefore, important to direct attention to the local level and analyze the role that local governments are playing in climate adaptation policy-making in urban areas.

Based on that, the objectives of this paper are: first, it explores the elements that enable local governments to take action in terms of climate adaptation and discusses the risks and vulnerability of cities looking at the implementation of climate change adaptation strategies. Second, it contributes with the emerging literature regarding cities and climate change with focus on adaptation that calls for a better 
understanding of the governance aspects of climate adaptation especially in urban areas where climatic stressors might be major sources of losses and deaths (SATTERTHWAITE et al., 2009). In order to do so, a comprehensive review of the literature on cities and climate change has been done. This article draws on findings available from different researches and analyzed case studies in Europe, North America, Latin America, Africa and Australia in order to raise issues that are enabling cities to engage in climate adaptation planning and implementation.

Many studies have shown the limitations and barriers experienced by local governments in implementing climate adaptation actions leading to questions of implementation and the governing of climate adaptation in the local arena (WILSON, 2006; STOBJÖRK, 2007). This literature has mostly adopted case study methodology and concentrated on individual countries, mostly in the global North such as the USA, the UK, Canada, Australia, Sweden and Norway ${ }^{3}$ or on individual transnational city/municipal networks. Studies that go beyond one or two cities are scarce as international comparative approaches including cases in the global South ${ }^{4}$ (BULKELEY et al., 2009; ALBER \& KERN, 2008; BULKELEY \& BETSILL, 2003; BULKELEY \& KERN, 2006; KERN et al., 2005). Moreover, there are very few studies that take into account and analyze the implementation and governance of climate adaptation taking place at the local level.

However, the empirical evidence shows that local governments (municipal or provincial) often appear as key actors in coordinating, facilitating and implementing climate change actions alone or cooperating with an array of different actors (STORBJÖRK, 2007) as these governments are closer to where the impacts of climate change will happen and have the potential to undertake both mitigation and adaptation policies (PUPPIM DE OLIVEIRA, 2009). However, less attention has been given to the challenges of climate adaptation in terms of policy strategies and instruments to adapt to the current and future impacts of climate change (CARMIN et al., 2009).

\footnotetext{
${ }^{3}$ For the UK and Germany, see Bulkeley \& Kern (2006); also for the UK, see Wilson (2006) and Lindley et al. (2006); for Sweden, see Granberg \& Elander (2007) and Storbjörk (2007); for Norway, see Lindseth (2005); for the USA and Australia, see Hamin \& Gurran (2008); for the UK, the USA and Canada, see Ligeti, Penney \& Wieditz (2007).

${ }^{4}$ For many cases in the Global South, see Bicknell, Dodman \& Satterthwaite (2009). Particularly, see the case studies in South Africa for the city of Durban (ROBERTS, 2008; 2009) and Cape Town (MUKHEIBIR \& ZIERVOGEL, 2007; 2009). Carmin et al. (2009) have analyzed Durban (South Africa) and Quito (Ecuador).

R. Inter. Interdisc. INTERthesis, Florianópolis, v.7, n.2, p. 241-275, jul/dez. 2010
} 
The first sections look at the governance of climate change from global to local and the role of local governments in urban climate policy followed by a discussion on vulnerability and risks in urban areas. Then, the role of local governments in climate change policy making is discussed followed by the analysis of vulnerability and climate risks in urban areas. The last section shed some light on the challenge of implementing climate change adaptation policies at the local level considering the elements that support and enable these actions.

\section{CLIMATE CHANGE AS BOTH GLOBAL AND LOCAL PROBLEM}

Climate change has been recognized by a large number of international organizations, scientific bodies, business organizations and governments as well as the international media as a critical problem for the present and future - a global problem requiring multi-level solutions (GUPTA, 2007; GIDDENS, 2008; 2009; BULKELEY \& BETSILL, 2003).

In the beginning, the nation-state was seen as having a critical role in governing global climate change through the formation of international agreements and their national implementation. Many scholars have been focusing on the interaction of nation-states through a variety of approaches and different methods of analysis (BULKELEY \& BETSILL, 2003). Though, signing international agreements is only one dimension of the policy process surrounding climate change.

The scholarship and the political sphere have focused mostly on the challenges at the global and regional (e.g. European Union) levels, examining the limits of the international and supranational political framework to deal with such issues. One of the most recurrent debates discusses the most appropriate level for taking action and who takes action as the nation-state is not the only actor to play. This can vary considerably across the different disciplines and increasing attention has been given to the role of non-state actors over the last few years as concepts of governance are not limited to states and governments as sole actors, but it is marked by participation of a myriad public and private non-state actors at all levels of decision-making, raging from networks of experts, environmentalists and multinational corporations to new agencies set up by governments (BIERMANN et 
al., 2008; GUPTA, 2007).

The cross-cutting challenge of climate change requires the analysis of all levels of governance, from global to local, taking into consideration the ways in which social and political processes interact across different levels and systems of governance. In order to engage with these processes that shape political will and local capacity for climate change action it is necessary to go beyond the local and look at the multiple levels and scales of governance in order to examine why are these actions taking place or not (BULKELEY \& BETSILL, 2005; 2003). Thus, the analysis of cities and climate change requires the analysis of process taking place simultaneously across scales that is not easily captured by either international relations or by the local development approaches.

Governments have traditionally been seen as the local of governing, defining and coordinating collective goals and actions. The emergence of new forms of governance and its practice suggest that it is no longer possible to take for granted the context within which policy-making takes place. According to Hooghe \& Marks (2003, p. 233) modern governance is dispersed across multiple centers of authority. This applies to a number of services and policies where local decisions are better taken and the outcomes more sensitive to varying scales efficiencies from policy to policy as central government is not suited to accommodate diversity most of the time. For instance, in the case of climate change, ecological and socio-economical conditions and its vulnerabilities vary from area to area. Implementing such policies or strategies in different areas poses different challenges. Also, perceptions and preferences of citizens may vary considerably across regions, within a state or a province and the process of policy-making should take such heterogeneity into account. The multilevel governance approach allows decision-makers to 'adjust' the scale of governance to reflect the abovementioned heterogeneity (see fig. 1). 


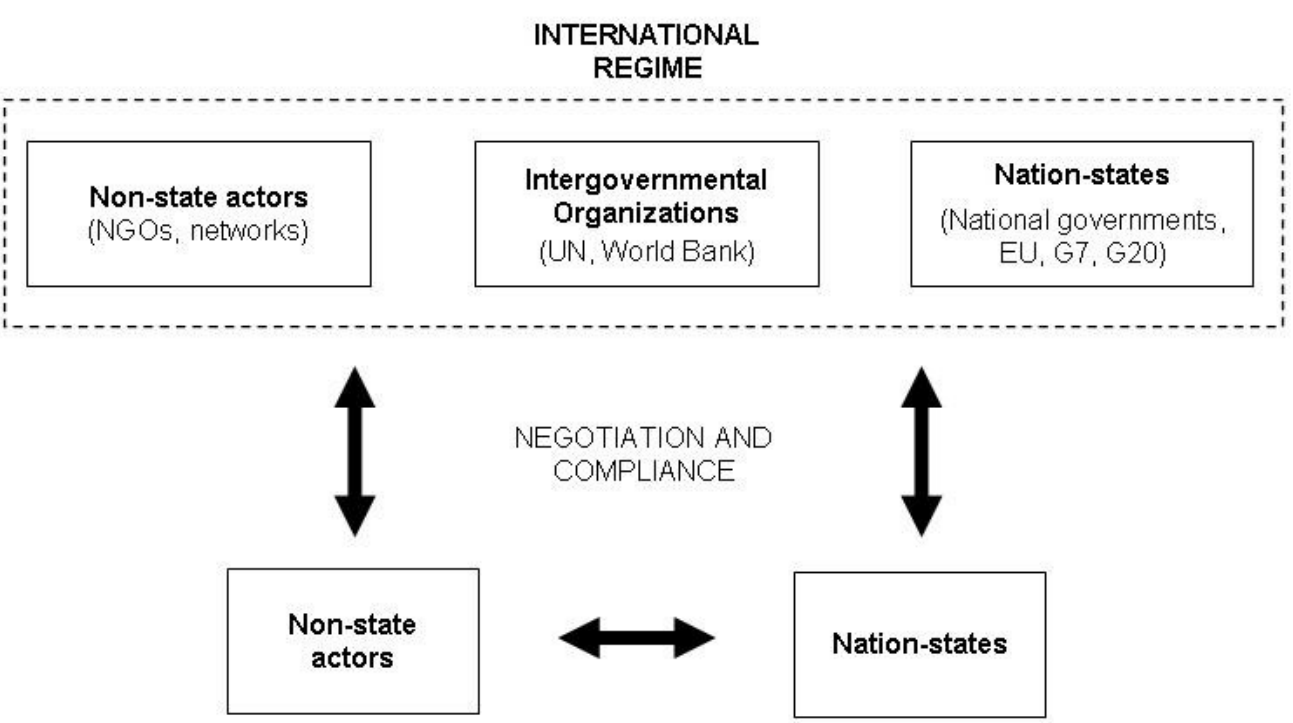

IMPLEMENTATION

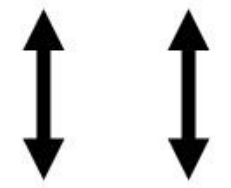

Individuals, institutions, organizations, private sector

(societal structures, decision-making processes, behavior)

Figure 1 - Multilevel governance approach

Source: The authors. Based on Bulkeley \& Betsill (2003).

The United Nations Conference on Environment and Development, also known as the Rio Summit in 1992 presented a first step towards global action on the issue of climate change. During this summit, the Framework Convention on Climate Change (FCCC) was signed followed by the negotiations and ratification of the Kyoto Protocol by many countries ${ }^{5}$. The responsibilities for implementing the commitments laid primarily with the national governments who have signed the convention, although important countries such as the United States of America has not ratified the Kyoto Protocol. Analysis of climate change policies has thus largely focused on global and regional levels of governance. The vast majority of research concerning the climate change governance has focused on the development of the international regime and its implementation ${ }^{6}$ (OKEREKE, BULKELEY \& SCHROEDER, 2009). However, climate change has an important local dimension as most human activities

\footnotetext{
${ }^{5}$ See Schroeder \& Bulkeley (2009) for a review of this process.

${ }^{6}$ For some examples of these literature, see Biermann (2005); Dessai \& Schipper (2003).

R. Inter. Interdisc. INTERthesis, Florianópolis, v.7, n.2, p. 241-275, jul/dez. 2010
} 
that can lead to and be affected by climate change are local (WILBANKS \& KATES, 1999).

While the framework of international negotiations remains important, cities are now greatly acknowledged as critical arenas in which the governance of climate change is taking place (SCHROEDER \& BULKELEY, 2009; BULKELEY et al., 2009; SATTERTHWAITE, 2008). Within academic and policy communities this recognition led to an increased interest in framing climate change as an urban problem and the debate on cities and climate change has increasingly been given attention in research communities dedicated to studying environment-society and populationenvironment interactions (LANKAO, 2007a; BETSILL \& BULKELEY, 2007; BULKELEY \& KERN, 2006; HOGAN, 2009; 2007).

The conclusion of the Kyoto Protocol negotiations was an important milestone (BETSILL \& BULKELEY, 2007). By then there was increasing movement of subnational governments and local communities working to place climate change politically on the local agenda. Since then many cities around the world have developed their own climate change strategies and some saw climate change as an opportunity to promote more sustainable patterns of urbanization (LANKAO, 2007a).

The development of an urban approach to climate change governance draws mostly from the emergence of transnational municipal networks. A number of municipal governments mainly in North America and Europe were pioneers in joining these national and transnational coalitions in late 1980s and early 1990s. In the beginning the focus of these initiatives was to adopt greenhouse gases (GHGs) emission targets (SCHROEDER \& BULKELEY, 2009). The most significant examples of these networks are the Cities for Climate Protection (CCP $)^{7}$, an initiative of the International Council for Local Environmental Initiatives (ICLEI), the Climate Alliance of European Cities ${ }^{8}$, and Energie-Cités ${ }^{9}$. Most of what has been done on urban governance and climate change was result of these three networks ${ }^{10}$.

Up until now, mitigation has received much more attention than adaptation in climate change policy at all levels of governance, from global to local (OJIMA, 2009;

\footnotetext{
${ }^{7}$ For more information, see ICLEl.org, Cities for Climate Protection (CCP), http://www.iclei.org (last visit Jun. 10 2009).

${ }^{8}$ For more information, see The Climate Alliance for European Cities, http://www.climateforchange.net (last visit Jun. 10 2009).

${ }^{9}$ For more information, see Energie-Cité.eu, http://www.energie-cites.eu (last visit Jun. 10 2009).

${ }^{10}$ For a review of this process, see Schroeder \& Bulkeley (2009).

R. Inter. Interdisc. INTERthesis, Florianópolis, v.7, n.2, p. 241-275, jul/dez. 2010
} 
SATTERTHWAITE et al., 2009; BULKELEY et al., 2009). At the international level, the parties to the UNFCCC in 2005 took a first important step on adaptation by adopting two funds, a Least Developed Countries Fund and a Special Climate Change Fund. The parties to the Kyoto Protocol in 2007 then adopted an Adaptation Fund, funded through the Clean Development Mechanism (CDM). Despite these first steps, financing adaptation is all but settled as the needs go beyond by far the current available funding (BULKELEY et al., 2009; AYERS, 2009a; 2009b).

Most climate change policies and city programs at the local level have focused primarily on mitigation and reducing emissions of GHGs. Lately, there is growing attention to the need of adaptation to reduce vulnerabilities, increase resilience and manage impacts, risks and damages arising from current and future climate variability and change. According to Alber \& Kern (2008), climate change transnational networks that have largely concentrated on mitigation for many years began to extend their interest to adaptation around five years ago. It includes the working group Global Warming - Local Warming coordinated by Eurocities and created by British cities and the European Commission in 2003; the AMICA initiative by the Climate Alliance of European Cities that proposes an integrated methodology to address both mitigation and adaptation in 2005 and ICLEI that has included adaptation into its Strategic Plan in 2006. These efforts whether focusing on mitigation, adaptation or both involve more than a thousand local governments in North America, Europe, Australia, Japan and more recently increasing participation from local governments in South and South East Asia and Latin America (BULKELEY et al., 2009; BETSILL \& BULKELEY, 2007).

\section{THE ROLE OF LOCAL GOVERNMENTS}

A wide variety of countries have increased the authority of local governments in order to make them more responsive and effective. In many countries it had happened in the aftermath of dictatorships; in others it was a strategy to reduce the size and participation of the central government and increase public involvement and 
accountability in governmental decision-making ${ }^{11}$. The foundation for having strong local governments is that only they can act to address certain key issues in regard to the public good likewise the provision of infrastructure and services essential for welfare and economic activities and regulate and control the actions of individuals, households and enterprises (SATTERTHWAITE et al., 2007; ROBINSON \& GORE, 2005).

Urban governance has been receiving greater attention in the last years. The development of new forms of democratic local governance in the global South are now well documented ${ }^{12}$ and better urban planning is being treated through systemic approaches taking the urban system as reference (BICKNELL, DODMAN \& SATTERTHWAITE, 2009; HOGAN \& MARANDOLA JR, 2009). These approaches that consider urban systems as part of the global ecosystem have brought the discussion on how to build sustainable urban development to the debate (NEWMAN \& JENNINGS, 2008; FERREIRA, 2000).

Regarding climate change, it is related to cities and local governments in at least three different ways (ALBER \& KERN, 2008; BULKELEY \& BETSILL, 2005). First, an important share of GHGs emissions is generated in cities especially megacities in developing and developed countries and there is great need for mitigation (LANKAO, 2007b; DODMAN, 2009; METZ et al., 2007). Second, the impacts of climate change have direct implications on cities, their infrastructure and population and they need to adapt to the changing situation (SATTERTHWAITE et al., 2009; SATTERTHWAITE, 2008; SATTERTHWAITE et al., 2007; MOSER \& SATTERTHWAITE, 2008). Third, linkages and synergies between climate change policies, urban sustainability and sustainable development become more evident at the local level and encourage cities to engender social and technological innovations (BULKELEY, 2006; LANKAO, 2007b). Many local governments are already familiar with sustainable development policies such as the implementation of Agenda 21 and they have the potential to develop city-scale pilot projects that can disseminate best practices.

\footnotetext{
${ }^{11}$ The current multiple system of governing local communities is often interpreted in terms of these forms of enabling authority although traditional governing mechanisms such as hierarchical relations between the central and local levels, service delivery and different kinds of regulation remain important (BULKELEY \& KERN, 2006; DAVIES, 2002).

12 See Cabannes (2004) and Fernandes (2007) for Brazil; Velasquez (1998) for Colombia; Hordijk (2005), López Follegatti (1999) and Diaz et al. (1996) for Peru, among many others.

R. Inter. Interdisc. INTERthesis, Florianópolis, v.7, n.2, p. 241-275, jul/dez. 2010
} 
Typically mitigation is dealt from the global to the national levels. Adaptation has the opposite pathway. As the impacts of climate change are essentially local, the adequate governance scale for analysis should be those closest to the individuals and communities (ADGER, 2005). As a result, the process of adaptation is strongly influenced by local choices, collective actions that are territorially visible in the city scale (TANNER et al., 2008). It justifies the importance of the involvement and analysis of local governments in terms of adaptation. The quality of local governance is crucial to deal with climate risks. Generally most local governments in the global South, where the majority of the world's urban population reside, has considerable authority in terms of statutory and legal frameworks but low institutional capacity to deal with climate change adaptation (BARTLETT et al., 2009; SATTERTHWAITE, 2008; TANNER et al., 2008; SATTERTHWAITE et al., 2007; WILBANKS et al., 2007). Table 1 shows a brief review of most common responsibilities in relation to climate adaptation held by local (and subnational) governments worldwide. Usually these governments are responsible for:

1. Finance: financial management and municipal budget; local taxes and fees;

2. Engineering and public infrastructure: building and preservation of the public space;

3. Urban and local development: land use regulation, zoning, building codes and urban planning, etc;

4. Public health, water and waste management: water resources management and distribution, pollution control, solid waste management, hospitals, etc.

5. Social policies: housing, education, youth, elderly.

6. Civil defense and emergency services: disaster preparedness and response, firemen and fire brigade, emergency services and rescue.

7. Public administration and human resources: a number of tasks and responsibilities concerning the city/municipal management;

8. Food production: a number of initiatives that can support and enhance food security at the local level. 
Table 1 - Local (subnational) government participation and responsibility in some actions concerning climate change adaptation

\begin{tabular}{|c|c|c|c|c|}
\hline Role of local government & $\begin{array}{l}\text { Long-term } \\
\text { planning }\end{array}$ & $\begin{array}{l}\text { Disaster } \\
\text { prevention }\end{array}$ & $\begin{array}{l}\text { Extreme climate } \\
\text { events response }\end{array}$ & Rebuilding \\
\hline \multicolumn{5}{|l|}{ Built Environment } \\
\hline Building code & High & n.a. & High & High \\
\hline Land use regulation / zoning & High & Weak & n.a. & High \\
\hline Public space preservation & High & Weak & n.a. & High \\
\hline Urban planning & High & n.a. & High & High \\
\hline \multicolumn{5}{|l|}{ Infrastructure } \\
\hline Water management & High & Weak & High & High \\
\hline Sanitation & High & Weak & High & High \\
\hline Drainage & High & Weak & High & High \\
\hline Streets, avenues and bridges & High & n.a. & High & High \\
\hline Energy & High & Weak & High & High \\
\hline Landfills & High & Weak & n.a. & High \\
\hline \multicolumn{5}{|l|}{ Services } \\
\hline Firemen and fire brigade & High & Weak & High & Weak \\
\hline Police and public order & Medium & High & High & Weak \\
\hline Solid waste management & High & High & High & High \\
\hline Education & Medium & Medium & n.a. & n.a. \\
\hline Public health & Medium & Medium & High & High \\
\hline Public transport & Medium & High & High & High \\
\hline Social welfare & Medium & High & High & High \\
\hline Disaster response and civil defense & n.a. & n.a. & High & High \\
\hline
\end{tabular}

Source: Adapted from Satterthwaite (2008, p. 26).

Effective climate change adaptation can bring significant improvements in many of these areas. Many authors argue that it is impossible to convene an effective adaptation program without knowledgeable, accountable, better resourced and technically competent local government who are willing to work with those most at risk (BARTLETT et al., 2009; SATTERTHWAITE, DODMAN \& BICKNELL, 2009). Well-governed cities have populations and economies that are resilient to a broader range of shocks and stresses, including extreme weather and other events that bring disasters that should be avoided. As vulnerability and risk are shaped by the local context and the level of exposure of people and infrastructure, local governments have to protect their inhabitants from floods and storms and ensure high quality of life through the provision of infrastructure, services, public space (SATTERTHWAITE, DODMAN \& BICKNELL, 2009). 


\section{VULNERABILITY, RISK AND THE NEED FOR ADAPTATION IN URBAN AREAS}

Urban areas are particularly vulnerable to the effects of climate change. Half of the global population currently lives in urban areas and by 2050 this proportion is estimated to increase (UNFPA, 2007). In addition, more then 80 percent of cities are located near coasts and rivers, making them predisposed to increased storms, floods and sea-level rise. The increasing trend in urbanization will make their inhabitants more vulnerable also to changes in the supply of water, food, energy and other resources as well as to the urban heat-island effect (BULKELEY et al., 2009; RIBEIRO, 2008a; LOMBARDO, 1985).

Urban centers concentrate a high proportion of those most at risk from the impacts of climate change, particularly in developing and least develop countries (MOSER \& SATTERTHWAITE, 2008). There are increasing case studies of specific cities highlighting the risks arising from extreme weather events, sea-level rise, freshwater availability and stresses on local food production ${ }^{13}$ (BICKNELL, DODMAN \& SATTERTHWAITE, 2009).

It is not possible to generalize about the likely risks of climate change as the nature and scale of risks vary between different locations, physical conditions and population groups (RIBEIRO, 2008a). People's capacity to avoid hazard, to cope with it and to adapt and reduce future risk is influenced by individual/household and community resources coupled with natural and context-specific characteristics, and cultural values and principles. The risks are interconnected between locations and level of infrastructure and service provision (MOSER \& SATTERTHWAITE, 2008). However, the lack of attention to the risks faced by large number of the urban centers threatens many people exposed to the likelihood of climate change impacts including storms, flooding, landslides and heat waves (HARDOY \& PANDIELLA, 2009a; 2009b).

Although extreme climatic events can affect everywhere and is very difficult to project its occurrence and intensity, the high level of risks is more evident for those who live in dangerous areas and lack the resources and options to modify their vulnerability. According to Liverman (1990), vulnerability is the degree to which a

\footnotetext{
${ }^{13}$ See Moser \& Satterthwaite (2008, p. 4) for a review of these case studies.

R. Inter. Interdisc. INTERthesis, Florianópolis, v.7, n.2, p. 241-275, jul/dez. 2010
} 
system or unit, in this case a city, is likely to experience harm due to perturbations or stresses. In the human dimensions of global environmental change community, vulnerability is also identified in terms of system exposure to crises, stresses and shocks; inadequate system capacity to cope and consequences and poor system recovery (DE SHERBININ, SCHILLER \& PULSIPHER, 2007; 2009; MOSER, 2008). This approach suggests that the most vulnerable to climate change are those that are more exposed to perturbations or stresses and have the weakest capacity to respond and to recover. Moser (1998) also defined vulnerability as insecurity in the wellbeing of individuals, households and communities. It is understood in terms of lack of resilience to changes that threaten welfare. These changes usually bring increasing risk and uncertainty (MOSER \& SATTERTHWAITE, 2008).

The way urban centers have been developing and the socio-economic inequality observed in many of these cities especially in global South means that vulnerability exists with or without climate change (SATTERTHWAITE, 2008; RIBEIRO, 2008a). Nevertheless, climate change and its impacts are likely to worsen the current situation in many of these places.

There is growing interest in identifying public policies and institutional arrangements that enable or hinder climate adaptation. In this context, adaptation policies are considered actions implemented by the State alone in its different levels of governance or in partnership with other actors and stakeholders (RIBEIRO, 2008b). Apart from the longer-term climate change, adaptation is also relevant to be taken into policy consideration for existing climatic variation and extreme weather events. Limits to our current levels of adaptation were demonstrated by losses and damages associated with extreme events such as droughts and floods. Such events continue to result in economic losses and human harm especially in developing countries (SATTERTHWAITE et al., 2009; DODMAN, HARDOY \& SATTERTHWAITE, 2009; RIBEIRO, 2008a; SATTERTHWAITE et al., 2007). Successful adaptation can reduce vulnerability by building on and strengthening existing coping mechanisms regarding climate change vulnerability with specific actions, and integrating vulnerability reduction into wider policies (MITCHELL \& TANNER, 2006).

Adaptation to climate is not something new. Throughout the history, societies have effectively adapted to climate variability by altering settlements, agriculture, and 
other aspects of their economies and lifestyle. To be successful, adaptation must go on at different levels at the same time, from global to local. Adaptation is essentially 'local' as the direct impacts of climate change are felt locally and response must be tailored to meet local needs. However, in many cases these strategies must be supported and guided by national and international policies and programmes (CHANDANI \& MARTINS, 2009).

The increasing interest in adaptation to climate change is reflected in the evolution of the theory and practice of climate change vulnerability assessments (FÜSSEL \& KLEIN, 2006), although consistent discussions of the theory and practice of climate adaptation is more recent and for many policy-makers are still confusing in terms of scales of necessary responses and relevance in policy agendas (ADGER et al., 2005a; ADGER et al., 2005b). For many policy-makers and local authorities climate adaptation is difficult to interpret through available information and increasingly adaptation is described or perceived as an unprecedented policy and management challenge (DOVERS, 2009). Even if there is political will to address it, there is no simple solution. It involves intense planning and modeling in areas of improving but still uncertain science, engaging diverse stakeholders and challenging fundamental assumptions held by people working in different disciplinary and institutional contexts (PARNELL, SIMON, VOGEL, 2007). It is also complex and multifaceted and impacts will depend on physical and socio-economic vulnerability, natural and human adaptive capacity, urban infrastructure, health services and disaster risks management (ALBER \& KERN, 2008).

Adaptation refers to both the process of adapting and the condition of being adapted. The term can have more specific interpretations in particular disciplines. Many definitions have been proposed through the climate change literature some referring only to societal adaptation (SMIT et al., 1999). Adaptation can be to climate change, to change and variability or just to climate. It can be in response to adverse effects or vulnerabilities but it can also be in response to opportunities to current or expected impacts. The common definition of adaptation refers to adjustments in ecological-social-economic systems in response to actual or expected climatic stimuli, their effects and impacts (IPCC, 2001). 


\section{ADAPTING CITIES TO CLIMATE CHANGE}

Research on urban climate change policy emerged more than a decade ago ${ }^{14}$ (BETSILL \& BULKELEY, 2007). Over the years, the literature that focused on climate change in urban areas tended to focus on mitigation rather than adaptation and the research on cities and urban adaptation is still in its early stages (LINDSETH, 2005; NAESS et al., 2005; ALBER \& KERN, 2008; BULKELEY et al., 2009) although there are calls to give greater attention to adaptation in the research on local climate policy (GRANDBERG \& ELANDER, 2007). Also most of the adaptation literature has covered ecological changes or has focused on agriculture and rural areas (SATTERTHWAITE et al., 2009; MOSER \& SATTERTHWAITE, 2008) and adaptation policies at the local level are still in their infancy ${ }^{15}$ (ALBER \& KERN, 2008; ZAHRAN et al., 2007; LINDSETH, 2005).

Although the local level appears and is suggested to be the optimal level for adaptation, the development of local adaptation plans in terms of climate change only started recently and, thus, research on local adaptation strategies to climate change and its governance is limited (BARTLETT et al., 2009; CARMIN et al., 2009). However, there are convincing arguments for a more robust consideration of adaptation as a response to climate change (SATTERTHWAITE et al., 2009). Also, most adaptations to climate change reduce the risks associated with current climate variability, which is a significant hazard in many world regions. The benefits from urban adaptation can be direct for the city as adaptation provides many local improvements (BULKELEY et al., 2009). The development of more competent, capable and accountable local governance structures is a fundamental primary step in addressing climate adaptation (SATTERTHWAITE, DODMAN, BICKNELL, 2009).

The review around the current urban responses to climate adaptation policies has shown that it can vary considerably and a number of factors appear to support its implementation in cities. However, what actually facilitates or holds back climate adaptation and the adaptive capacity of particular places is clearly context dependent (STORBJÖRK, 2007).

Framing climate change at the local level and implementing climate adaptation

\footnotetext{
${ }^{14}$ See Collier (1997) for one of the first works in this field focusing on mitigation.

15 The possible reason for that is that adaptation is a recent agenda for most local authorities. Comment made by Dr Susanne Moser in personal communication on 01/13/2009.

R. Inter. Interdisc. INTERthesis, Florianópolis, v.7, n.2, p. 241-275, jul/dez. 2010
} 
is not easy. Several studies have demonstrated a mismatch between various socioeconomic and environmental policies that have effect on climate adaptation in different levels of governance including the local (FERREIRA, 1998; 1999) ${ }^{16}$. STORBJÖRK (2007) highlighted the emergence of conflicts when trying to govern climate adaptation in the local arena in Sweden. Demeritt \& Langdon (2004) showed communication gaps and mismatches between the UK Climate Change Programme and local authorities in the UK. These studies point to the direction that to effectively address the issue of climate change, local governments have to overcome a number of barriers in terms of communication, policy making and participation. The governing of climate change adaptation rely on a number of strategies and instruments that have to be applied to the local governance structures in other to promote effective local actions that are widely accepted by the different stakeholders.

Local governments have the central role in climate adaptation within their jurisdiction and it is obvious that they need a supportive institutional, regulatory and financial framework from higher levels of government (SATTERTHWAITE, 2008). The political and institutional constraints on local governments' ability to develop appropriate policies and measures for climate adaptation are still not recognized in much of the literature on adaptation (SATTERTHWAITE et al., 2007).

Based on the review of several case studies (see table 2), the elements that support climate adaptation include the impact of climate change at the local level and the perception of the vulnerabilities and risks by citizens and policy-makers; the cities capability and authority to regulate climate-relevant issues and areas; national programme(s) to support local initiatives specially from those local governments that lack the resources to follow the pioneers (GUPTA, 2007); the engagement of cities in national and transnational networks which facilitate the exchange of experiences and the transfer of best practices (ALBER \& KERN, 2008; BULKELEY, 2006); the presence of a committed political and/or executive champion(s) that can put climate adaptation on the agenda and develop it as a policy entrepreneur ${ }^{17}$ (BULKELEY \& KERN, 2006); the creation of a specific interagency or interdepartmental organization to lead the adaptation process ensuring the collaboration of relevant stakeholders; the collaboration of a local community of strong researchers prepared to work with local governments on climate change impacts and adaptation - science-policy

\footnotetext{
${ }^{16}$ Several case studies analysed for Brazil.

17 See Kingdon (1995) for the definition of policy entrepreneur.

R. Inter. Interdisc. INTERthesis, Florianópolis, v.7, n.2, p. 241-275, jul/dez. 2010
} 
interaction (CASH \& MOSER, 2000; LEMOS \& MOREHOUSE, 2005); the allocation of financial and human resources; strong communication and outreach; the ability to set feasible objectives and priorities; and stakeholder engagement strategy (LIGETI, PENNEY \& WIEDITZ, 2007).

Table 2 - Elements that support the implementation of climate adaptation at the local level

\begin{tabular}{|c|c|}
\hline 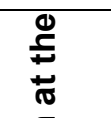 & $\begin{array}{l}\text { Impacts of climate change and perception of vulnerabilities and risks by citizens and } \\
\text { policy-makers; }\end{array}$ \\
\hline 호 & City's capability and authority to regulate climate-relevant issues and areas; \\
\hline$\frac{\pi}{\frac{\pi}{\pi}}$ & $\begin{array}{l}\text { National programme(s) to support local initiatives (specially from those local } \\
\text { governments that lack resources); }\end{array}$ \\
\hline 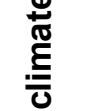 & $\begin{array}{l}\text { Engagement in national and transnational networks to facilitate exchange of } \\
\text { experiences and transfer of 'best practices'; }\end{array}$ \\
\hline 峞 & $\begin{array}{l}\text { Committed political champion(s) to put climate change on the agenda and develop it } \\
\text { as policy entrepreneur; }\end{array}$ \\
\hline 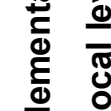 & $\begin{array}{l}\text { Creation of specific interagency or interdepartmental organization to lead climate } \\
\text { adaptation; }\end{array}$ \\
\hline 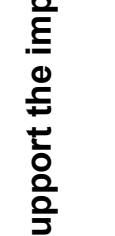 & $\begin{array}{l}\text { Collaboration of a local community of committed researchers that are prepared to work } \\
\text { with local governments on climate change impacts and adaptation; not only science- } \\
\text { policy interaction is necessary but also the participation of diverse stakeholders and } \\
\text { sectors such as different government agencies, industry, scientists and the people; }\end{array}$ \\
\hline$\stackrel{\pi}{\pi}$ & Allocation of financial and human resources; \\
\hline 我 & Strong communication and outreach; \\
\hline$\Phi$ & Ability to set feasible objectives and priorities; \\
\hline$\frac{\bar{\omega}}{\omega}$ & Stakeholder engagement strategy. \\
\hline
\end{tabular}

Source: The authors. Based on Alber \& Kern (2008); Gupta (2007); Bulkeley (2006); Bulkeley \& Kern (2006); Cash \& Moser (2000); Lemos \& Morehouse (2005); Ligeti, Penney \& Wieditz (2007).

On the other hand, there are many barriers that cities encounter in developing their adaptation policies and actions (see table 3 ). This literature shows many examples of barriers to implement such strategies, such as: weak understanding of climate change impacts and how these changes can impact life in the city; uncertainty about the timing and extend of some impacts that makes it difficult for policy-makers to set their priorities; focus on the short-term costs of adaptation rather than the long-term cost of 'business as usual' as most adaptation options require upfront investments; difficulty in getting attention and commitment of political leaders as local politicians have relatively short mandates and face more frequent elections

R. Inter. Interdisc. INTERthesis, Florianópolis, v.7, n.2, p. 241-275, jul/dez. 2010 
calling them to respond to problems that their constituents are facing now; problems coordinating it across local government departments or different levels of government; difficulties in involving some stakeholders that do not want to get involved; inadequate or lack of financial resources (LIGETI, PENNEY \& WIEDITZ, 2007); lack of a national strategy to guide local governments (GRANBERG \& ELANDER, 2007); mismatch between knowledge providers/scientific organizations and users/policy makers (STORBJÖRK, 2007; CASH \& MOSER, 2000).

One can argue that effective adaptation to climate change is contingent on the availability of information on what to adapt to and how to adapt, and resources to implement the adaptation measures. For a comprehensive climate policy at the local level it is necessary to have a collection of information about the particular locality (in terms of scientific research, data collection, model experiments, etc) and the availability of resources (in terms of financial means, technologies, expertise and tools among many others). It is also crucial to consider traditional knowledge and the way that traditional population have been dealing with climatic changes over the history.

Table 3 - Barriers and constraints encountered by local governments in implementing climate adaptation

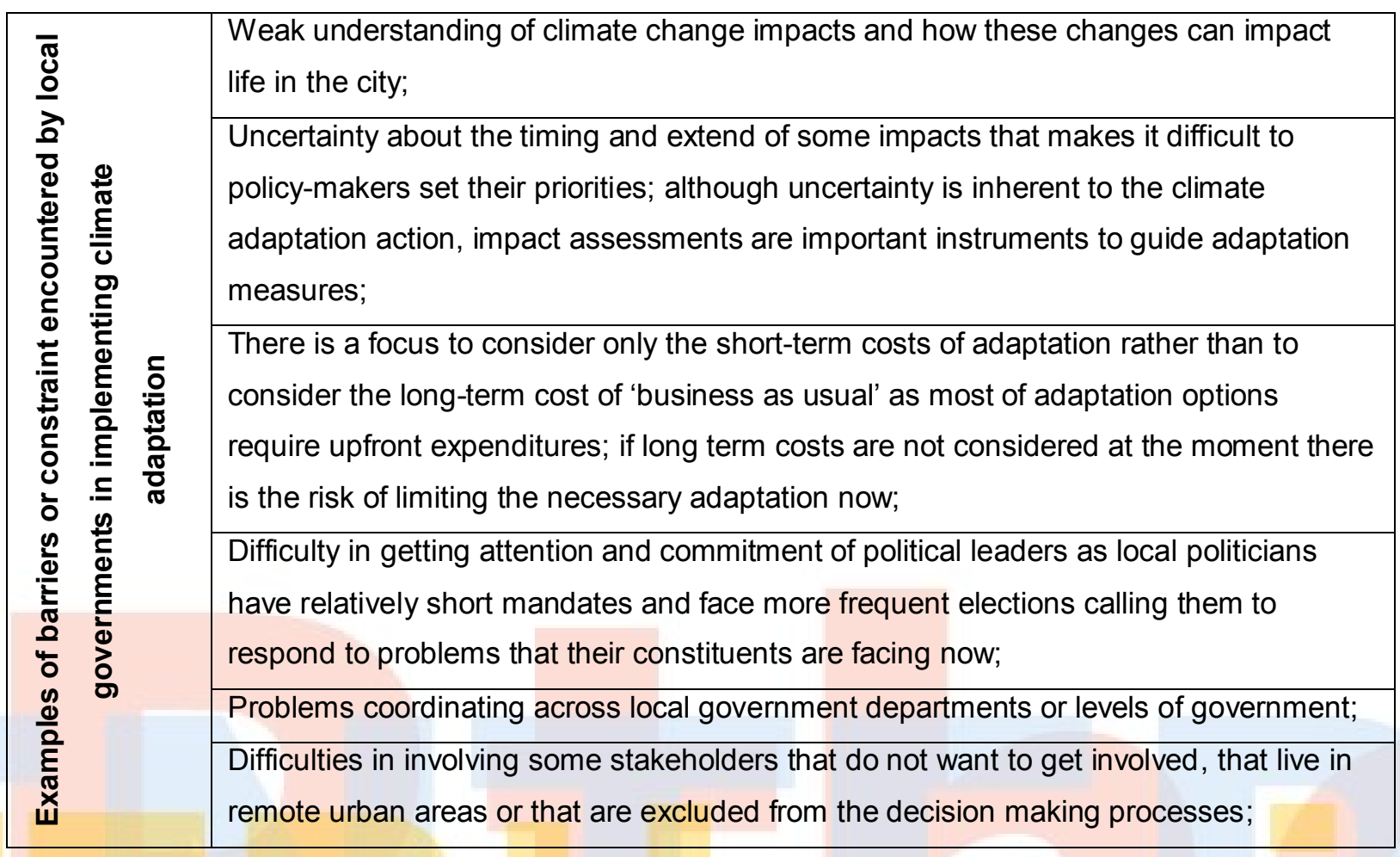

R. Inter. Interdisc. INTERthesis, Florianópolis, v.7, n.2, p. 241-275, jul/dez. 2010 


\begin{tabular}{|l|l|}
\hline \multirow{2}{*}{} & Inadequate or lack of financial resources; \\
\cline { 2 - 3 } & Lack of national strategy to guide local governments; \\
\cline { 2 - 3 } & $\begin{array}{l}\text { Mismatch between knowledge providers/scientific organizations and users/policy } \\
\text { makers. }\end{array}$ \\
\hline
\end{tabular}

Source: The authors. Based on Ligeti, Penney \& Wieditz (2007); Granberg \& Elander (2007); Storbjörk (2007); Cash and Moser (2000).

The case studies analyzed suggest that there is not a blueprint for implementing adaptation strategies at the local level. It is necessary a combination of several factors including different types of actors, resources, knowledge, data, stakeholder participation, governance arrangements and institutional and regulatory frameworks. These are all relevant for urban climate adaptation and lead to the local solutions for a global problem.

Rather than being influenced by external incentives or pressures like in the case for mitigation where there are robust activity of transnational networks and the international regime, the evidence shows that adaptation action is mostly driven by local action and rely on the physical and built environment, the perception of vulnerability and risks by citizens and policy-makers or a long history in dealing with natural hazards and disasters (SATTERTHWAITE, 2008; DODMAN, HARDOY \& SATTERTHWAITE, 2009). In general, these experiences suggest that cities may start adaptation action by developing general strategies to mobilize different areas of the public administration and society (ROBERTS, 2008; 2009; MUKHEIBIR \& ZIERVOGEL, 2009; 2007). Sector-based plans are also needed in order to have effective adaptation programs and goals (CARMIN et al., 2009).

However, to achieve these goals, some elements are important as follow.

\subsection{Resources and financial capacity}

The availability of financial and human resources is crucial for planning and implementing adaptation. Some adaptation measures require building or improving urban infrastructure that may be far beyond the financial capacity of the local government and in some cases even the national government. It links to the issue of funding for adaptation (AYERS, 2009a; 2009b). In some countries local governments

R. Inter. Interdisc. INTERthesis, Florianópolis, v.7, n.2, p. 241-275, jul/dez. 2010 
have more power and fiscal autonomy than others. But for many developing countries, there will be the need for additional funding for urban adaptation.

Despite the importance of financial resources, human and political resources are important to initiate and sustain climate adaptation policies (CARMIN et al., 2009). Well-trained and dedicated staff to take care of climate change adaptation planning seems to be an important feature from the cities that have initiated adaptation actions (ROBERTS, 2008; 2009; SATTERTHWAITE et al., 2009; SATTERTHWAITE, DODMAN \& BICKNELL, 2009). The leadership of a policy entrepreneur or a local champion to introduce climate adaptation in the local agenda and develop it over time is also central in order to mobilize resources and explore innovative ways sometimes even beyond the city's boundaries so that the lack of resources cannot be used as an excuse for doing nothing (SATTERTHWAITE, 2008).

\subsection{Knowledge and information}

Knowledge and information available to design and implement long-term adaptation measures at the local level is a major step in addressing adaptation to climate change. Some cities with capability to assess its vulnerability and develop scenarios show that having a good base of information about the impacts of climate change helps to foster action as decision makers can rely on some baseline information. It is common knowledge that decision-makers are not able to make decisions under great uncertainty. Climate change deals with high levels of uncertainty especially at the local level. So, efforts in the direction of offering guidance on where the critical areas are and how it can be attenuated seem to enable at the least the discussion about the options to be followed. Unfortunately, many studies have shown that the available data and climate change scenarios are low at the local level in general. Even when it is available there are many mismatches and communication gaps between the science and policy interface (CASH \& MOSER, 2000; BRADSHAW \& BORCHERS, 2000).

In some cases, a cross-scale approach is necessary to understand the nature

R. Inter. Interdisc. INTERthesis, Florianópolis, v.7, n.2, p. 241-275, jul/dez. 2010 
of the problem increasing the complexity and making it even harder to public officials understand and for scientists to frame the issue (CASH et al., 2006). In order to overcome these constraints, some cities have been making efforts in the direction of having access to information through the creation of spaces for sharing experiences and ideas with other cities (CARMIN et al., 2009). In these spaces, policy-makers, municipal officials, civil society representatives and scholars have the opportunity to discuss relevant issues for the city or for the region.

\subsection{Institutions and governance}

Enabling institutional frameworks and governance structures are important factors that support the implementation of adaptation measures at the local level (BULKELEY et al., 2009). Apart from knowledge and resources, a set of conditions shapes the capacity of local governments to act in terms of climate adaptation. Some examples include: democratic and participatory local governance and ability to dialogue and engage with different stakeholders such as the business sector, nongovernmental organizations, community-based organizations, academia, research centers; local legislations and building codes that allow local governments to plan the urban environment; the provision of infrastructure and service delivery; effective early warning systems and coordinated disaster response; health care and good hospitals (SATTERTHWAITE, 2008).

In some cases, local governments created specific offices to deal with climate changes issues. These offices are not affiliated to any department or previous sector within the local administration. By doing so, they were able to coordinate intergovernmental efforts from different departments and governmental bodies, engage with universities and other municipal governmental and have visibility and dedicated resources to implement climate adaptation actions (CARMIN et al., 2009).

Governments as static and bureaucratic organizations take time to change and internalize new issues and priorities (BERKHOUT, HERTIN \& GANN, 2006). So, instead of starting new plans or new policies, it seems easier to build upon initiatives that are already ongoing local projects and that the public servants and citizens are 
already familiar with. So, the local administration can set more general guidelines to establish a common vision among different areas of the public administration; then, in a second phase, sector-specific adaptation plans with targets and goals can be designed, implemented and achieved.

\section{CONCLUSION}

Impacts of climatic changes are likely to threaten hundreds of millions of people in several parts of the world, as they did to other species in other historical periods. A number of people live in vulnerable areas within urban centers and are exposed to many risks. The scale of these risks is much influenced by the quality of the urban infrastructure and the governance structures that plan, coordinate, manage and implement the provision of policies and services, and by higher frequency of extreme climatic events. This paper reviewed the literature on cities and climate change with focus on adaptation. It has also explored the elements that enable local governments to take climate adaptation action and discussed the risks and vulnerability of cities looking at the implementation of climate change adaptation strategies.

While science is advancing to provide increasingly reliable data, methodologies, tools and frameworks to help society adapt to the impacts of climate change, many countries and local governments are still struggling to provide even the most basic urban services. That is probably the one of the reasons why urban adaptation has been entering slowly into the policy realm. The lack of financial and human resources, the high level of uncertainty to the extent of impacts and the need for climate change scientific data at the local level also contribute to the lack of action toward adaptation.

Even though this paper was based on a limited collection of case studies available in the literature, it is possible to draw some lessons on what are the elements that enable and influence the implementation of urban climate adaptation. Some of them appear to be essential in implementing adaptation like an enabling institutional environment, good governance, democratic and participatory institutions, 
availability of different types of resources, knowledge and information on what and how to adapt and the presence of a local champion.

So far, mitigation has received greater attention from municipal governments worldwide. Now it is time to push adaptation forward. Mitigation and adaptation measures can have several synergies and be complementary at some levels, but they can also be contradictory. So, adaption is not a panacea for climate and environmental risks. It is necessary intense planning, participation, coordination of multilevel efforts and information for an effective adaptation.

\section{ACKNOWLEDGEMENTS}

We would like to thank the State of São Paulo Research Foundation (FAPESP 08/58159-7) and the Brazilian Federal Agency for Support and Evaluation of Graduate Education (CAPES) for financial support. We also acknowledge the hospitality granted by the Department of Environmental Policy Analysis, Institute of Environmental Studies (IVM), Vrije Universiteit Amsterdam, The Netherlands during visiting fellowship of one of the authors. Comments received from an anonymous reviewer helped to improve the original manuscript. 


\section{REFERENCES}

ADGER, W.N. Scales of Governance and Environmental Justice for Adaptation and Mitigation of Climate Change. Journal of International Development, v.13, n.7, p. 921-931, 2005.

ADGER, W.N.; ARNELL, N.W.; TOMPKINS, E. Adapting to climate change: perspectives across scales. Global Environmental Change, v.15, n.2, p. 75-76, $2005 a$.

ADGER, W.N.; ARNELL, N.W.; TOMPKINS, E. Successful adaptation to climate change across scales. Global Environmental Change, v.15, n.2, p. 77-86, 2005b.

ALBER, G.; KERN, K. Governing Climate Change in Cities: Modes of Urban Climate Governance in Multi-level Systems. In: OECD CONFERENCE ON COMPETITIVE CITIES AND CLIMATE CHANGE, 2008, Milan. Anais... Milan, 2008.

AYERS, J. International funding to support urban adaptation to climate change. Environment and Urbanization, v.21, n.1, p. 225-240, 2009a.

AYERS, J. International Funding to Support Urban Adaptation to Climate Change. In: BICKNELL, J.; DODMAN, D.; SATTERTHWAITE, D. (Eds). Adapting Cities to Climate Change: Understanding and Addressing the Development Challenges. London: Earthscan, 2009b, p. 339-358.

BARTLETT, S. et al. Social Aspects of Climate Change in Urban Areas in Low- and Middle Income Countries. In: WORLD BANK 5TH URBAN SYMPOSIUM ON CLIMATE CHANGE, 2009, Marseille. Anais... Marseille, 2009.

BERKHOUT, F.; HERTIN, J.; GANN, D.M. Learning to Adapt: Organisational Adaptation to Climate Change Impacts. Climatic Change, v.78, p. 135-156, 2006.

BETSILL, M.M.; BULKELEY, H. Looking Back and Thinking Ahead: A Decade of Cities and Climate Change Research. Local Governments, v.12, n.5, p. 447-456, 2007.

BICKNELL, J.; DODMAN, D.; SATTERTHWAITE, D. (Eds). Adapting Cities to Climate Change: Understanding and Addressing the Development Challenges. London: Earthscan, 2009, 397p.

R. Inter. Interdisc. INTERthesis, Florianópolis, v.7, n.2, p. 241-275, jul/dez. 2010 
BIERMANN, F. et al. Earth System Governance: People, Places and the Planet. Science and Implementation Plan of the Earth System Governance Project. Earth System Governance Report 1, IHDP Report 20. Bonn, IHDP: The Earth System Governance Project, 2009.

BRADSHAW, G.A.; BORCHERS, J.G. Uncertainty as information: narrowing the science-policy gap. Conservation Ecology, v.4, n.1, p. 7, 2000.

BULKELEY, $\mathrm{H}$. et al. Cities and Climate Change: The role of institutions, governance and urban planning. In: WORLD BANK $5^{\text {TH }}$ URBAN SYMPOSIUM ON CLIMATE CHANGE, 2009, Marseille. Anais... Marseille, 2009.

BULKELEY, $\mathrm{H}$. Urban sustainability: learning from best practice? Environment and Planning A, v.38, p. 1029-1044, 2006.

BULKELEY, H.; BETSILL, M.M. Cities and Climate Change: Urban Sustainability and Global Environmental Governance. London: Routledge, 2003.

BULKELEY, H.; BETSILL, M.M. Rethinking Sustainable Cities: Multilevel Governance and the 'Urban' Politics of Climate Change. Environmental Politics, v.14, n.1, p. 4263, 2005.

BULKELEY, H.; KERN, K. Local Government and the Governing of Climate Change in Germany and UK. Urban Studies, v.43, n.12, p. 2237-2259, 2006.

CABANNES, Y. Participatory budgeting: a significant contribution to participatory democracy. Environment and Urbanization, v.16, n.1, p. 27-46, 2004.

CARMIN, J.; ROBERTS, D.; ANGUELOVSKI, I. Planning Climate Resilient Cities: Early Lessons from Early Adapters. In: WORLD BANK $5^{\text {TH }}$ URBAN SYMPOSIUM ON CLIMATE CHANGE, 2009, Marseille. Anais... Marseille, 2009.

CASH, D.W. et al. Scale and cross-scale dynamics: governance and information in a multilevel world. Ecology and Society, v.11, n. 2, p. 8, 2006.

CASH, D.W.; MOSER, S.C. Linking global and local scales: designing dynamic assessment and management processes. Global Environmental Change, v.10, p. 109-120, 2000. 
CHANDANI, A.; MARTINS, R.D.A. Adaptation Technologies in the Post-2012 Framework. Report commissioned by CIDSE and Caritas Internationalis. Brussels: CIDSE, 2009.

COLLIER, U. Local Authorities and Climate Protection in the European Union: putting subsidiary into practice? Local Government, v.2, n.1, p. 39-57, 1997.

CONFALONIERI, U.E.C. et al. Mudanças globais e desenvolvimento: importância para a saúde. Script Nova, v. 11, n.3, p.139-154, 2002.

CONFALONIERI, U.E.C. et al. Human health. In: PARRY, M. et al. (Eds). Climate Change 2007: Impacts, Adaptation and Vulnerability. Contribution of Working Group II to the Fourth Assessment Report of the Intergovernmental Panel on Climate Change. Cambridge: Cambridge University Press, 2007, p. 391-431.

CONFALONIERI, U.E.C. Mudança climática global e saúde humana no Brasil. Parcerias Estratégicas, v.27, p. 323-349, 2008.

CONFALONIERI, U.E.C.; MARINHO, D.P.; RODRIGUEZ, R. Public Health Vulnerability to Climate Change in Brazil. Climate Research, v.40, p.175-186, 2009.

DAVIES, J.S. The governance of urban regeneration: a critique of the 'governing without government' thesis. Public Administration, v.80, n. 2, p. 301-322, 2002. DAWSON, R. Re-engineering Cities: A Framework for Adaptation to Global Change. Philosophical Transactions of the Royal Society A, v. 365, p. 3085-3098, 2007.

DE SHERBININ, A.; SCHILLER, A.; PULSIPHER, A. The vulnerability of global cities to climate hazards. Environment and Urbanization, v.19, n.1, p. 39-64, 2007.

DE SHERBININ, A.; SCHILLER, A.; PULSIPHER, A. The Vulnerability of Global Cities to Climate Hazards. In: BICKNELL, J.; DODMAN, D.; SATTERTHWAITE, D. (Eds). Adapting Cities to Climate Change: Understanding and Addressing the Development Challenges. London: Earthscan, 2009, p. 129-158.

DEMERITT, D.; LANGSDON, D. The UK Climate Change Programme and communication with local authorities. Global Environmental Change, v.14, p. 325336, 2004. 
DESSAI, S.; SCHIPPER, E.L. The Marrakech Accords to the Kyoto Protocol: Analysis and Future Prospects. Global Environmental Change, v.13, n.2, p. 149153, 2003.

DÍAZ, D.B.; FOLLEGATTI, J.L.L.; HORDIJK, M. Innovative urban environmental management in Ilo, Peru. Environment and Urbanization, v.8, n.1, p. 21-34, 1996.

DODMAN, D. Blaming Cities for Climate Change? An analysis of urban greenhouse gases emissions inventories. Environment and Urbanization, v.21, n.1, p. 185-201, 2009.

DODMAN, D.; HARDOY, J.; SATTERTHWAITE, D. Urban Development and Intensive and Extensive Risk. Contribution to the Global Assessment Report on Disaster Risk Reduction (2009). United Nations International Strategy for Disaster Risk Reduction (UNISDR). New York: UNISDR, 2009.

DOVERS, S. Normalizing Adaptation. Global Environmental Change, v.19, n.1, p.4-6, 2009.

FERNANDES, E. Implementing the urban reform agenda in Brazil. Environment and Urbanization, v.19, n.1, p. 177-189, 2007.

FERREIRA, L.C. A Questão Ambiental: Sustentabilidade e Políticas Públicas no Brasil. São Paulo: Boitempo Editorial, 1998.

FERREIRA, L.C. Indicadores Políticos-Institucionais de Sustentabilidade: Criando e Acomodando Demandas Públicas. Ambiente \& Sociedade, v.3, n.6/7, p. 15-30, 2000.

FERREIRA, L.C. La búsqueda de alternativas de sustentabilidad en el poder local. In: ZICCARDI, A.; LUJÁN, S. (org.). Ciudades Latinoamericanas. Modernización y Pobreza. Ciudad de México: Universidad Nacional Autónoma de México, 1999.

FOLLEGATTI, J.L. A city in transformation. Environment and Urbanization, v.11, n.2, p. 181-202, 1999.

FÜSSEL, H.M.; KLEIN, R.J.T. Climate Change Vulnerability Assessments: An Evolution of the Conceptual Thinking. Climatic Change, v.75, p. 301-329, 2006. 
GIDDENS, A. The Politics of Climate Change. Cambridge: Polity Press, 2009.

GRANBERG, M.; ELANDER, I. Local Governance and Climate Change: Reflections on the Swedish Experience. Local Environment, v.12, n.5, p. 537-548, 2007.

GUPTA, J. The multi-level governance challenge of climate change. Environmental Sciences, v.4, n.3, p. 131-137, 2007.

HAMIN, E.M.; GURRAN, N. Urban form and climate change: Balancing adaptation and mitigation in the U.S. and Australia. Habitat International, v.33, n.3, p. 238-245, 2009.

HARDOY, J.; PANDIELLA, G. Urban poverty and vulnerability to climate change in Latin America. Environment and Urbanization v.21, n.1, p. 203-224, 2009a.

HARDOY, J.; PANDIELLA, G. Urban Poverty and Vulnerability to Climate Change in Latin America. In: BICKNELL, J.; DODMAN, D.; SATTERTHWAITE, D. (Eds). Adapting Cities to Climate Change: Understanding and Addressing the Development Challenges. London: Earthscan, 2009b, p. 225-252.

HOGAN, D.J. Human dimensions of global environmental change. Ambiente \& Sociedade, v.10, n.2, p. 161-166, 2007.

HOGAN, D.J. População e mudanças ambientais globais. In: HOGAN, D.J.; MARANDOLA JR, E. (Orgs.). População e mudança climática: Dimensões humanas das mudanças ambientais globais. Campinas: Ed. UNICAMP, 2009. p. 1124.

HOGAN, D.J.; MARANDOLA JR, E. (Orgs.). População e mudança climática:

Dimensões humanas das mudanças ambientais globais. Campinas: Ed. UNICAMP, 2009.

HOOGHE, L.; MARKS, G. Unraveling the Central State, but How? Types of Multilevel Governance. American Political Science Review, v.97, n.2, p. 233-243, 2003.

HORDIJK, M. Participatory governance in Peru: exercising citizenship. Environment and Urbanization, v.17, n.1, p. 219-236, 2005. 
HUNT, A.; WATKISS, P. Literature review on climate change impacts on urban city centres: Initial findings. Organisation for Economic Co-operation and Development (OECD), ENV/EPOC/GSP(2007)10/FINAL, OECD Publishing, 2007.

HUNT, J. How can cities mitigate and adapt to climate change? Building Research \& Information, v.32, n.1, p. 55-57, 2004.

Intergovernmental Panel on Climate Change (IPCC). Climate Change 2001. Synthesis Report. Cambridge: Cambridge University Press, 2001.

Kingdon, J.W. Agendas, Alternatives and public policies. 2 ed. New York: Longman, 1995.

LANKAO, P.R. Are we missing the point? Particularities of urbanization, sustainability and carbon emissions in Latin American cities. Environment and Urbanization, v.19, p. 159-175, 2007b.

LANKAO, P.R. How do Local Governments in Mexico City Manage Global Warming? Local Environment, v.12, n.5, p. 519-535, 2007 a.

LEMOS, M.C.; MOREHOUSE, B.J. The co-production of science and policy in integrated climate assessments. Global Environmental Change, v.15, p. 57-68, 2005.

LIGETI, E.; PENNEY, J.; WIEDITZ, I. Cities Preparing for Climate Change: A Study of Six Urban Regions. Toronto: Clean Air Partnership, 2007, 74p.

LINDLEY, S.J. et al. Adaptation Strategies for Climate Change in the Urban Environment: Assessing Climate Change Related Risk in UK Urban Areas. Journal of Risk Research, v.9, n.5, p. 543-568, 2006.

LINDSETH, G. Local level adaptation to climate change: discursive strategies in the Norwegian context. Journal of Environmental Policy and Planning, v.7, n.1, p. 6184, 2005.

LIVERMAN, D. Vulnerability to global environmental change. In: KASPERSON, R.E. et al. (eds). Understanding Global Environmental Change: The Contributions of Risks Analysis and Management. The Earth Transformed Programme, Clark University, Worcester MA, 1990. p. 27-44. 
LOMBARDO, M. A. Ilha de calor nas metrópoles: o exemplo de São Paulo. São Paulo: Ed. HUCITEC, 1985.

MARENGO, J.A. Water and Climate Change. Estudos Avançados, v.22, n.63, p. 83-96, 2008.

MCGRANAHAN, G.; BALK, D.; ANDERSON, B. The Rising Tide: Assessing the Risks of Climate Change and Human Settlements in Low-Elevation Coastal Zones. In: BICKNELL, J.; DODMAN, D.; SATTERTHWAITE, D. (Eds). Adapting Cities to Climate Change: Understanding and Addressing the Development Challenges. London: Earthscan, 2009, p. 51-76.

MCGRANAHAN, G.; BALK, D.; ANDERSON, B. The rising tide: assessing the risks of climate change and human settlements in low elevation coastal zones.

Environment and Urbanization, v.19, n.1, p. 17-37, 2007.

METZ, B. et al. (Eds). Climate Change 2007 - Mitigation of Climate Change. Contribution of Working Group III to the Fourth Assessment Report of the IPCC. Cambridge: Cambridge University Press, 2007.

MITCHELL, T.; TANNER, T.M. Adapting to Climate Change: Challenges and Opportunities for the Development Community. Teddington: Tearfund, 2006.

MOSER, C. The Asset vulnerability framework: reassessing urban poverty reduction strategies. World Development, v.26, n.1, p. 1-19, 1998.

MOSER, C.; SATTERTHWAITE, D. Towards pro-poor adaptation to climate change in the urban centres of low- and middle-income countries. Discussion Paper N.3, International Institute for Environment and Development (IIED), London, 2008, 39p.

MUKHEIBIR, P.; ZIERVOGEL, G. Developing a Municipal Adaptation Plan (MAP) for climate change: the city of Cape Town. Environment and Urbanization, v.19, n.1, p. 143-158, 2007.

MUKHEIBIR, P.; ZIERVOGEL, G. Developing a Municipal Adaptation Plan (MAP) for Climate Change: The City of Cape Town. In: BICKNELL, J.; DODMAN, D.;

SATTERTHWAITE, D. (Eds). Adapting Cities to Climate Change: Understanding and Addressing the Development Challenges. London: Earthscan, 2009, p. 271-290. 
MULLER, M. Adapting to Climate Change: Water Management for Urban Resilience. In: BICKNELL, J.; DODMAN, D.; SATTERTHWAITE, D. (Eds). Adapting Cities to Climate Change: Understanding and Addressing the Development Challenges. London: Earthscan, 2009, p. 291-309.

NAESS, L. et al. Institutional adaptation to climate change: flood responses at the municipal level in Norway. Global Environmental Change, v.15, p. 125-138, 2005.

NEWMAN, P.; JENNINGS, I. Cities as Sustainable Ecosystems: Principles and Practices. Washington DC: Island Press, 2008, 284p.

OJIMA, R. Perspectivas para adaptação frente às mudanças ambientais globais no contexto da urbanização brasileira: cenários para os estudos de população. In: HOGAN, D.J.; MARANDOLA JR, E. (Orgs.). População e mudança climática: Dimensões humanas das mudanças ambientais globais. Campinas: Ed. UNICAMP, 2009, p. 191-204.

OKEREKE, C.; BULKELEY, H.; SCHROEDER, H. Conceptualizing Climate Governance Beyond the International Regime. Global Environmental Politics, v.9, n.1, p. 58-78, 2009.

PARNELL, S.; SIMON, D.; VOGEL, C. Global Environmental Change Conceptualising The Challenge for Cities in Poor Countries. Area, v.39, n.3, p. 357369, 2007.

PARRY, M. et al. (Eds). Climate Change 2007 - Impacts, Adaptation and Vulnerability. Contribution of Working Group II to the Fourth Assessment Report of the IPCC. Cambridge: Cambridge University Press, 2007.

PUPPIM, J.A.O. The implementation of climate change related policies at the subnational level: an analysis of three countries. Habitat International, v.33, p. 253259, 2009.

RIBEIRO, W.C. Impactos das mudanças climáticas em cidades no Brasil. Parcerias Estratégicas, v.27, p. 297-321, 2008a.

RIBEIRO, W.C. Políticas públicas ambientais no Brasil: mitigação das mudanças climáticas. In: Diez años de cambios en el Mundo, en la Geografía y en las Ciencias Sociales, 1999-2008. COLOQUIO INTERNACIONAL DE GEOCRÍTICA, 10, 2008, Barcelona. Anais... Barcelona: Universidad de Barcelona, 2008b. 
ROBERTS, D. Thinking globally, acting locally - institutionalizing climate change at the local government level in Durban, South Africa. Environment and Urbanization, v.20, n.2, p. 521-537, 2008.

ROBERTS, D. Thinking Globally, Acting Locally: Institutionalizing Climate Change at the Local Government Level in Durban, South Africa. In: BICKNELL, J.; DODMAN, D.; SATTERTHWAITE, D. (Eds). Adapting Cities to Climate Change:

Understanding and Addressing the Development Challenges. London: Earthscan, 2009, p. 253-270.

ROBINSON, P.J.; GORE, C.D. Barriers to Canadian Municipal Response to Climate Change. Canadian Journal of Urban Research, v.14, n.1, p. 102-120, 2005.

SATTERTHW AITE, D. Climate Change and Urbanization: Effects and Implications for Urban Governance. United Nations Expert Group Meeting on Population Distribution, Urbanization, Internal Migration and Development, UN/POP/EGMURB/2008/16, New York, 2008, 29p.

SATTERTHWAITE, D. et al. Adapting to Climate Change in Urban Areas: The possibilities and constraints in low- and middle-income nations. Discussion Paper N.1, International Institute for Environment and Development (IIED), London, 2007, $107 p$.

SATTERTHWAITE, D. et al. Adapting to Climate Change in Urban Areas: The Possibilities and Constraints in Low- and Middle-Income Nations. In: BICKNELL, J.; DODMAN, D.; SATTERTHWAITE, D. (Eds). Adapting Cities to Climate Change: Understanding and Addressing the Development Challenges. London: Earthscan, 2009 , p. 3-50.

SATTERTHWAITE, D.; DODMAN, D.; BICKNELL, J. Conclusions: Local Development and Adaptation. In: BICKNELL, J.; DODMAN, D.; SATTERTHWAITE, D. (Eds). Adapting Cities to Climate Change: Understanding and Addressing the Development Challenges. London: Earthscan, 2009, p. 359-384.

SCHROEDER, H.; BULKELEY, H. Global Cities and the Governance of Climate Change: What is the Role of Law in Cities? Fordham Urban Law Journal, v.36, n.2, p. 313-359, 2009.

SMIT, B. et al. The Science of Adaptation: a framework for assessment. Mitigation and Adaptation Strategies for Global Change, v.4, p. 199-213, 1999. 
SOLOMON, S. et al. (Eds). Climate Change 2007 - The Physical Science Basis. Contribution of Working Group I to the Fourth Assessment Report of the IPCC. Cambridge: Cambridge University Press, 2007.

STORBJÖRK, S. Governing Climate Adaptation in the Local Arena: Challenges of Risk Management and Planning in Sweden. Local Environment, v.12, n.5, p. 457469, 2007.

TANNER, T.M. et al. Urban Governance for Adaptation: Assessing Climate Change Resilience in Ten Asian Cities. IDS Working Paper 315. Brighton: Institute for Development Studies (IDS), 2008. 47p.

UNITED NATIONS POPULATION FUND (UNFPA). State of World Population 2007. Unleashing the Potential of Urban Growth. Nova York: UNFPA, 2007. 108 p.

VELASQUEZ, L.S. Agenda 21: a form of joint environmental management in Manizales, Colombia. Environment and Urbanization, v.10, n.2, p. 9-36, 1998.

WILBANKS, T.J; KATES, R.W. Global Change in Local Places: How Scales Matters. Climatic Change, v. 43, p. 601-628, 1999.

WILBANKS, T.J. et al. Industry, settlement and society. In: PARRY, M. et al. (Eds). Climate Change 2007: Impacts, Adaptation and Vulnerability. Contribution of Working Group II to the Fourth Assessment Report of the Intergovernmental Panel on Climate Change. Cambridge: Cambridge University Press, 2007. p. 357-390.

WILSON, E. Adapting to Climate Change at the Local Level: The Spatial Planning Response. Local Environment, v.11, n.6, p. 609-625, 2006.

ZAHRAN, S. et al. Risk, Stress and Capacity. Urban Affairs Review, v.43, n.4, p. 447-474, 2008. 